\title{
The Influence of Political Parties on the Third Power
}

\author{
Stefan Machura \\ Bangor University, School of Social Sciences \\ Bangor, Gwynedd, LL57 2DG, UK
}

Tel: 44-1248-382214Ｅ-mail: s.machura@bangor.ac.uk

A German version was published as "Der Einfluss der Parteien auf die dritte Gewalt" in: R. Walkenhaus, S. Machura, P. Nahamowitz, \& E. Treutner (Eds.), Staat im Wandel. Festschrift für Rüdiger Voigt (pp. 263-280). Stuttgart: Steiner 2006.

\begin{abstract}
It is inevitable that the political parties exert some influence on courts since courts are entrusted with major political functions and it is parties which organize political actions. However, there is much concern about illicit practices in various states. Factors of the political structure and the "institutional design" of the state, the career paths and inner mechanics of the legal institutions and a nation's legal culture shape the degree of party power on the courts and the prosecutorial service.
\end{abstract}

Keywords: Political Parties, Third Power, Courts, Political Influence, Patronage, Judicial Independence

\section{Introduction}

The law-giver entrusts the judges with a large part of the political steering of the society (Voigt, 1986, pp. 13-14). Be it the criminalisation of certain behaviour, the distribution of rights for actors on markets or the legal obligations and rights of citizens faced with state authority, courts are "law in action". No wonder that political actors have an interest in courts. In most democracies, the main political actors outside the state are the political parties. Parties can be defined as organisations founded to take part in elections, to offer a political programme and to place their followers in power positions.

Today, the influence of political parties on the judiciary is more topical than ever. As late as in the 1980ies, the number of the states which provided the judicial review of the most important decisions of governments and parliaments was estimated at about sixty. The American political scientist Henry J. Abraham (1987) wrote that this legal provision may have functioned in a dozen of these countries, at best. Today, there are much more. In December 2004, the Ukrainian Constitutional Court annulated the fraudulent presidential election and ordered a new election which saw the victory of the opposition candidate. Before, the Ukraine was part of the Soviet Union, a state in which judges were recipients of orders and a constitutional court did not exist.

But also in other regards, the decisions of the third power have become more important since Abraham's observation. In Italy, investigations of judges and prosecutors have caused the political system to collapse. The judiciary as hammer and the upset public as anvil: the landscape of political parties splintered under the blow (details in Nelken, 1996). Only a statuary limitation saved Italy's later Prime Minister Silvio Berlusconi from a conviction related to the bribing of a judge. He felt so threatened from what he perceived as a justice infiltrated by left-wingers (Polaczek, 2002), that he tried to limit the courts by law. In his distress he did not even shy back from attempting to forbid judges any party membership.

In Germany, the parliamentary opposition has since long developed the habit to counter symbolic decisions of the majority by appealing to constitutional courts. But also the governing forces often leave unpopular decisions happily to the judiciary. Not only on the federal and the province level, but also in local disputes, the courts are often involved (See e.g. Scharpf, 1970; Blankenburg, 1995, pp. 109-113).

Even these few remarks show that the importance of the justice system in the political life can be great. It is therefore not surprising that the political parties try to influence the third power. Kunig (2001, p. 77) holds the "Politisierung" of the selection of judges at supreme courts for system immanent. But the parties' influence should not only be analysed as aimed and reflected. Parties as organisations perform a pivotal social task: they organise the political work (Luhmann, 2000, pp. 266-267). But beyond, they tend to treat every problem which with they come into contact as a political problem. "The parties attract new problems", said Niklas Luhmann (2000, p. 215, my translation). Everything the 
parties can get hold of, is dealt with partially under the point of view of the coming into and the keeping of power. Party critics like the former German President Richard von Weizsäcker, a successful politician himself, have attacked this way of parties to expand into all areas of life.

For our topic and for German circumstances, the big "Volksparteien" (catch-all parties) are the most relevant actors. The liberal FDP, the Linkspartei (former Party of Democratic Socialism) and the Green Party have not only less influence on the justice system because of their lower percentage of votes. The two Volksparteien, the Social Democrats und and the Christian Democrats, significantly tend to make the decisions on key positions of the justice system between themselves (note 1). This observation also underlines the importance of this topic for politics and political science. (Note 2)

This paper aims to treat the following topics: At first, a systematisation of the opportunities is important, which allow the political parties to exert an influence. In this way, secondly, an assessment of the degree of the political parties' influence on the German justice system today can be reached.

The influence of parties on the third power makes itself felt over the following channels:

a. the determination of its organisational structure

b.the decision programme

c. the personnel politics

d. the allocation of material resources for the justice system, especially financing

e. the provision of information and training

f. the intervention in individual cases (note 3).

But first, it is important to remember the special function of the third power within the state.

\section{Third Power}

Montesquieu mentioned the three "powers" of the state (Montesquieu 1748/1974, 11th vol., 6th ch.; Strohmeier 2004). He described a law-giving, an executive and as a third, the judicial "power" of the state. The distribution of state powers should result in a system of mutual control. Montesquieu did not favour a strict separation of powers, because this means each of the powers could do what it wants in its realm. They would be uncontrolled. In Italy for example, the administration and control of the courts falls within their strict autonomy. As a result, there are no threats or incentives coming from outside for judges to work efficiently. Trials and appeals are notoriously delayed and judges can not be confronted with this.

Montesquieu suggested a division of power. Executive und legislative are subject to controls from the other (Schwan, 1991, pp. 218-219). A system of checks and balances emerges. Yet, it has to be said that the third power is less part of this pattern of mutual control. With good reason, a "Rechtsstaat", a states governed by the rule of law, tries to keep the working of the justice system free from interferences. In this case, it can be somehow at least warranted that the actions of the state are bound by law, that citizens are sheltered against transgressions of state agencies and private actors alike, and that state power is exerted rationally (about the criteria of a "Rechtsstaat", e.g., Karpen 1985: 15-16). So, a distinction has to be made between illicit interferences into the work of prosecution and courts and a more general influence on them which stops early enough to keep the third power's necessary discretion to reliably and independently address legal problems.

Parliaments and governments have procedures providing proper legitimation which support them in times of trouble. The democratic legitimation of the third power remains weak. In Germany, it comes very indirect, e.g., from special committees. In the "Richterwahlausschüsse", representatives of the legislative and executive take part in the selection of judges. In the majority of countries, judges are not elected directly by the people. The most notable exception is formed by the U.S. as will be seen. In Germany and in many other countries, only the lay judges represent an element of direct democratic control. The budget of the third power is another area which highlights its dependence from the other state powers. The parliament's budget approval may be understood as a source of regular democratic legitimation.

Impressed by the impact of mass media, the notion of fourth power became common. The media should be independent and they should have an eye on the state powers. Similar to the media, the courts and the prosecution are left on their own in their daily operations. Attempts to intervene would quickly be answered by mistrust and resistance. The third power forms a more independently working system of organisations within the society and the state. The organisation of the courts is multiply structured by area specific and territorial competences (jurisdictions). As an additional safeguard for independent judgement in the realm of criminal law, the prosecution is separated from the judges.

Regardless of how much effort is undertaken to secure the independence of the third power, it remains dependent on outputs from other sections of the society (the following is influenced by Luhmann, 1983, 1993 and 1999). The third power consumes resources which have to be produced and which can not be used for other purposes. Their provision is rectified by the infrastructure which courts offer to the society. The apparatus of the third power is kept running for a 
legal solution of social conflicts. It safeguards the expectations of those relying on the law (Röhl, 1987, p. 536). Only rarely, the judicial organs can act out of own initiative. A claim has to be forwarded or an offence has to be reported to start it on. The authority of the courts has to be broadly supported throughout the society, only then they can function effectively (for institutions Easton, 1965, for courts Machura, 2003). This also applies to their decisions which have to be obeyed and if it is only reluctantly, which reminds on Max Weber's concept of legitimacy (Weber, 1922/1973, pp. 470 and 1922/1980, pp. 16 and 123).

\section{Respect for the independence of courts}

The respect for the independence of judges displayed in a Rechtsstaat thus appears as an indispensable legal-cultural remedy for the comparably weak standing of the third power amongst the state institutions. Where this attitude is not taken for granted, the third power remains helpless. To give an example, the former Russian President Boris Yeltsin simply declared the Constitutional Court as "suspended", when he faced with a state crisis in 1993. Since then, the Constitutional Court shies away from confrontations with the Kremlin (Epstein, Night \& Shvetsova, 2001). In June 2007, the Ukraine suffered a severe crisis when President Yushchenko dismissed judges of the Constitutional Court after alleged corruption (Juschtschenko, 2007), which the opposing party's government denied (Schuller 2007a). Even worse, the dismissal of the General Prosecutor by the President, the appointment of a presidential candidate and the subsequent storming of the office by special police headed by the Minister of the Interior in person was short to spark a civil war. Police troops loyal to the President and those loyal to the government already lined up (Schuller 2007b). Only later, the parties stroke a compromise. On 9 March 2007, Pakistan's President General Perves Musharraf dismissed the highest judge of his country, Iftikhar Chaudry. He declared the judge was corrupt, while the judge's supporters said the President aimed to secure his re-election. Also, Chaudry investigated cases of "disappeared" persons (Buchsteiner 2007a). Musharraf accused him to endanger the fight against terrorists. A Protest movement, involving a significant number of lawyers, resulted and Justice Chaudry became a "folk hero" (Ladurner 2007). "Confronting sliding public support, General Musharraf had little option later but to accept a ruling by the Supreme Court that the Chief Justice should be reinstated." (Buncombe \& Waraich, 2007, p. 2) In early November, Musharraf sensed that the Court may declare his re-election unconstitional, so he declared state emergency, placed Chaudry and colleagues under house-arrest, and appointed new judges (Buchsteiner 2007b).

A completely different picture is provided by the Italian state crisis following the 1992 Tangentopoli investigations against illegal party financing. When threatened politicians tried to intervene into the course of justice, the public alarmed by the media - who in turn were informed by prosecutors and investigating magistrates - stood up against them. News pictures showed how an angry crowd of citizens let small money rain on the assembled classe politique. The people in the end also decided the fate of the Kaczynski government in Poland 2007. The opposition won parliamentary elections. But before, the government has used the public prosecution which in Poland receives orders from the Justice Minister to open investigation against opposing politicians and even to arrest people (Frankfurter Allgemeine Zeitung 2007a, 2007c, p. 1; Schuller 2007c). The Polish Supreme Court had to publicly criticise the government for its demand that the courts shall not rule according to law but according to "state reason" (Frankfurter Allgemeine Zeitung 2007b).

Not in vain, all too direct interferences into the third power are surrounded by a taboo. Heavy media criticism would be likely (for an example Rudolph, 1998). Consequentially, a strict silence is most likely observed about political intervention, if it occurs. They are rarely made public. In Germany, an exception is made for the selection of constitutional court judges (Kunig, 2001, p. 77, Schmid, 1975, pp. 123-124). Political struggles are much more public, here. When it comes to the decisions of the Federal Constitutional Court, the information for the public already tends to be much more reluctant. Where the court splits in a vote of 4 to 4 along the lines of political party affiliation, the names of judges are most likely not reported in order to not display the party political dimension (Bryde, 1998, p. 503). Journalistic or scholarly interest into the party politics of courts is sometimes answered with rejection (Note 4). "Do not ask, do not talk."

In the following, an attempt is made to identify the channels which have been used by political parties in Germany and in other countries to influence the third power.

\section{Organisational Structure}

"Organisation structure is programme structure"tells the organisation theory (Häußermann, 1977, p. 82). The way how organisational units are tailored pre-structures the work to be done, delineates areas of competence and creates responsibility. Even more, the organisational design also touches the relevant social surrounding with all its divergent interests which are connected to an institution.

A good example for the sometimes explosive nature of organisational measures is provided by the "justice war" in the German Province North Rhine-Westphalia about eight years ago. Its former Prime Minister Wolfgang Clement presumably only wanted to demonstrate his readiness to save money and to reform state administration when he stirred up a political hornet's nest. The idea to combine the Ministry of the Interior with the Justice Ministry encountered fierce 
protest from the judges. It would be irreconcilable with the idea of a "Rechtsstaat" to place the police and the prosecution - both subject to political orders - as well as the judges who are to remain independent under the rule of one ministry. In their own affairs, the courts in form of the Province Constitutional Court decided against the government plan and stopped it. - Quite recently, English judges protested against the reform idea to grant additional powers to the Justice Ministry to include supervision of the prisons. The BBC showed the judges in a long procession with wigs and gowns.

In Germany, indeed, the judiciary and the prosecution differ in that the hierarchy principle is much more important for the prosecutors (Müller, 1980, p. 202). Prosecutors may receive orders and "wishes" from the Federal or Province Justice Ministry (Rudolph, 1998; Rautenberg, 2000). At this interface of politics and justice system, there are often frictions. In the Nineties, for example, a highly regarded legal scholar who has just been appointed by his party for the post of the General Prosecutor, stepped down under protest. The government of the province had tried to order him to continue investigations into the death of the former Province Prime Minister Uwe Barschel, even after the prosecutors had searched for years and there was no reason left to continue other than to exploit things politically. On the Federal level and in some provinces, German General Prosecutors can be dismissed at any time without having to give a reason (Rautenberg, 2000).

Following their ideas, parties can give priority to certain fields of criminal prosecution. The foundation of specialized prosecutorial units forms an organisational measure which results in increased success of investigations and in more convictions. Independently from the law which goes unchanged the legal practice can thus become different. This also provides an example for the effects of organisational decisions.

Not only the foundation, but also the dissolution of institutions sparks off reasoning as to whose political advantage it is done. On 14 December 2004, the German newspaper Frankfurter Allgemeine Zeitung reported a story under the headline "Revenge for the Pilz-Trial" (own translation - S.M.). Suspicion had been voiced that the city of Mühlhausen would have to loose its High Court with the attached prosecutorial office following reorganisation measures. Allegedly, the prosecution had too eagerly inquired the case of the CD-manufacturer Pilz who used to be a protégé of the provincial government. The former affaire had resulted in the justice minister having to step down after he tried to sabotage inquiries against Pilz.

The formation of judicial circuits can be not less political as the formation of electoral districts. Conservative Southerners in the U.S. tried in the Sixties to separate South Carolina and Virginia from a federal circuit with more liberal judges. The plan was vigorously opposed by civil rights activists (Jacob, 1984, p. 14).

But the upholding of judicial structures may also be in the interest of parties. In the German province of North Rhine-Westphalia, the office of the lay mediator ("Schiedsperson") is supported from both big political parties, the Christian Democrats (CDU) and the Social Democrats (SPD). Unpaid lay mediators are dealing with minor offences and small claims, mainly. They are appointed and financed by the local bodies and supervised by the local courts. The institution offers the political parties an opportunity to broaden their influence symbolically (Note 5). Perhaps, this explains why the lawmakers of North Rhine-Westphalia try since years to uphold the institution despite a lack of interest from the public. Few people forward their conflicts to "Schiedspersonen". However, the lay mediators perform quite well (Machura \& Weiß, 2003; Röhl \& Weiß, 2004; Röhl \& Weiß, 2005).

\section{Decision Programme}

Up to now the organisation of the third power was dealt with. The following turns to the programme which underlies decisions of courts and prosecutors. Parties influence it via governments and parliaments. They let their ideas flow into laws and decrees. The jurisdiction is bound to the law ("Recht und Gesetz" in Germany by constitution). The dominant legal doctrine of positivism orders the judge to decide according to the written law primarily. Only if this law is not sufficiently detailed, other sources of law are to be used. The strongest binding to the law appears in the realm of criminal law. In Continental European countries like Germany and Italy, the prosecutor has to inquire an offence and has to prosecute it eventually whenever it is heard of. David Nelken argues that this provision shields the Continental European criminal justice much better against the temptation of political opportunism compared to, e.g., the U.S. In the U.S, the prosecutors have more discretion and they are more frequently politically exploited (Nelken, 1996). - To conclude, the binding of the third power to the law opens up more general and abstract opportunities for control by the parliamentary majority and its parties but it restricts attempts to intervene in particular cases.

Sometimes it becomes visible that parties have formed the law to their advantage. From time to time, German commentators criticise that offences against the provision to report donations to parties are "only" punished as an administrative offence by the President of the Federal Parliament. But there is no criminal responsibility.

Some countries openly have privileges in their criminal law for the holders of public offices. The Russian penal code has harsh sanctions for some crimes when they are committed by ordinary citizens, while public servants would have to face more lenient sentences. "Preferential treatment of the rulers through law" this has been termed (Schroeder, 1998, 
33). As Vincenzo Ruggiero reports, French law allowed to remove cases of political corruption from investigating judges. They then were transferred to specially assigned higher judges who were selected according to political criteria. According to a later regulation, the French General Prosecutor has the power to remove cases from a juge d'instruction if it is seen as in the "best interest" of the administration of justice (Ruggiero, 1996, pp. 119-110 and 127). - This already touches the area of cadre politics.

\section{Personnel}

The parties' personnel policy in public institutions constitutes almost a taboo, especially when the justice system is at issue. Within reasonable limits every citizen should have an interest in judges and prosecutors fulfilling certain demands. It might be enough to remind the fate of the Weimar Republic. Very early, Social Democrats like Ernst Fraenkel had criticised that only a tiny minority of the judges took the side of the Republic (Fraenkel, 1968). The renunciation to replace judges contributed to the demise of the democratic system. As a consequence, the Federal Republic of Germany demands from its personnel loyalty to the democratic state. This also applies to legal personnel.

It is a task for legal politics to decide on general criteria for the qualification and selection of jurists who serve in the third power. The gender mainstreaming policy, e.g., proved a success in Germany. As a rule, about $50 \%$ of all posts are now given to female candidates. In about a generation, there will be as many women as men working in the legal system. The abolishment of a more social scientific lawyer education in the early $1980 \mathrm{ies}$, however, could count as an overhasty decision. No neutral systematic evaluation was undertaken and the conservative's fear could prevail. Still, the education of lawyers is divided into an initial legal-dogmatic part in the law faculties and an apprenticeship within legal institutions. Newcomers are introduced into the routines of the existing system and in many cases they are devoid of any means to critically evaluate and change the practice where necessary.

The German parties play a key role in the selection of judges for the high courts, having their followers in the selection committees. All considered the parties did not only fill posts in proportion to the number of votes received. They also looked at the qualification and personal suitability of the candidates (Note 6). Abuses such as those reported from the U.S. appeared less often. Langbein even notices a structural difference between U.S. and German courts:

"... the decision to isolate important components of constitutional and administrative-law jurisdiction outside the ordinary courts in Germany lowers the political stakes in judicial office, by comparison with our system, in which every federal district judge (and for that matter, every state judge) purports to brandish the Constitution and thus to be able to wreak major social and political change." (Langbein, 1985, p. 853)

The re-election of George W. Bush resulted in fears that he would use the opportunity to shape the political preferences of the U.S. Supreme Court for decades (Gelinski, 2004; Mejias, 2004). Liberals sometimes stated that this is the true significance of the election. Indeed, the U.S.A. is the most important research area for political scientists interested in the selection of judges. In the U.S., judging is no career profession as in Continental Europe where young judges start immediately after their education and in which they climb further on the job ladder. U.S. judges should be experienced lawyers and there are political elections and appointments for all their offices. On the Federal level, the judges are all politically appointed while the U.S. states have varying procedures ranging from direct elections to appointments (Meador, 1991; Nagel, 1975, p. 32). These decisions are often highly political. The office of a prosecutor even forms a major platform for political careers. American scholars report a quality deficit of judges and prosecutors caused by one-sided political selection (prominently Langbein, 1985, pp. 848-855). They say that while in Continental Europe the best young lawyers join the judiciary or the prosecution, facing a foreseeable career ladder, aspiring young lawyers in the U.S. would avoid the state service and enter the big law firms instead.

\subsection{Other influences may be worse}

But before all the blame is put on the American political parties, it is advisable to have a close look at the state of California which elects judges directly. There, law firms are among those who pay for the judges' campaigns. They care that million-dollar-claims are processed by thankful judges (Note 7). The example may serve as a warning. All criticism to political parties considered, without parties with their internal balancing out of different interest groups, other forces would reach out to influence the courts largely unchecked (about lobbies Gawron \& Schäfer, 1976).

The famous (first) Mannesmann-Prozess in the German city Dusseldorf (Legnaro, 2004) shows some of this. "Even business personalities should acknowledge that we are in a Rechtsstaat", a speaker from the courts has been quoted (Meinke, 2003). Before she acquitted high-ranking managers, the presiding judge stated to have been pressured by defence, prosecution, "politicians of all colours", media and the public (Peitsmeier, 2004). The judge later said, only a critique on the colour of her lipstick had resulted in her changing her opinion.

\subsection{Assessing the reach of party influence}

Not much can be said on whether posts on the lower levels of the justice system are acquired by party membership. Interviews resulted in a mixed picture. There exists one older empirical study from 1972 which touches this question 
(Werle, 1975). At this time, the judges held that "the personnel policy influence of parties" did not constitute a threat of their judicial independence (Werle, 1975, p. 152). However, there is a talk that "only the small lower court judge ("Der kleine Amtsrichter") who does not reflect on a career really is independent". Because, otherwise the decisions of a judge might easily be influenced by what superior justices write in the judge's personnel file. But Werle's (1975, p. 172) remark might still be true: judges tend to use the concept of judicial independence as a tool to articulate problems with how work is organised in the courts. At least in those German provinces which are held by one political party since decades, it is assumed that the intermediate level of managers in legal and administrative authorities act "ahead of obedience" ("vorauseilender Gehorsam"). Neumann (1979, pp. 157-158) wrote that powerful senior judges aspiring a career at the Federal Courts which needs political support may influence judges lower in rank.

In addition to German high courts, the filling of posts in proportion to the number of votes received by parties comes obvious for lay judges. Germany has a lay assessor-system, some of which are selected without the requirement of special qualification. These are the "Schöffen" at criminal court, the honorary administrative court judges and in practice many "Schöffen" at juvenile court, too. In interviews, "Schöffen" repeatedly said, they came into office because "the party" suggested them (interviews for Machura, 2001). It is a long established practice, that the major parties place their followers and members on the lists of possible lay assessors. By this, they reward followers this way. But also, they want to outbalance the influence of other parties on lay and professional judges. Arguably, this works, similar as the jury in the U.S. curbs the powers of judges and public prosecutors.

In 2000, lay assessors at the lower administrative courts of an East and a West German province have been compared: Hesse and Saxony-Anhalt (Machura, 2006 and 2007). The political parties have not yet developed strong roots in the Eastern part of Germany, which before 1989 was governed by the elite of the Communist Party. The one exception is the "Partei des Demokratischen Sozialismus" (PDS, recently renamed "Linkspartei"), the successor of the former Eastern Communist Party. In the West, especially the Christian and the Social Democrats have developed a strong net of support and they command the allegiance of large parts of the society. This constellation allows observing how well established party structures can influence the composition of the lay judges. The party sympathies of lay assessors have been asked for (Table 1). In the Western province of Hesse, 78\% indicated their allegiance to either the Christian or the Social Democrats. In the Eastern province of Saxony-Anhalt, both parties only had the sympathies of $41 \%$, roughly half of their share in Hesse. (See Table 1)

Regardless of the filling of posts of professional or lay judges, the parties hope that their candidates will act according to their programme once in office. Yet, this is not sure. A number of empirical studies deal with the decisions of U.S. judges. The results differ. However, after reviewing 84 studies, Pinello summarizes: "Democratic judges indeed are more liberal on the bench than Republican counterparts" (Pinello, 1999, p. 243). Perhaps, in countries with a multi-party system like Germany, things are more complicated. It does not have the allegedly clear distinction of two polar political camps but a lot more of overlap. Hubert Rottleuthner showed regular coalitions between judges from different camps in his analysis of the decision behaviour at the German Federal Constitutional Court (Rottleuthner, 1987, pp. 106-110). This is a consequence from the essence of judicial work: In their decisions, judges answer to a specific case. Finding an opinion can be very personal, involving various aspects of a lifetime's experience. For judges, the formation through the internal career patterns of the courts is more decisive than "outside" factors like party preferences (Rottleuthner, 1987, p. 110; Machura, 2001, p. 31). Legal scholar Brun-Otto Bryde, himself a Federal Constitutional Court Judge, wrote about the former party politicians among the judges of his court:

"Freed from party discipline and the necessity to take voters into account, they sometimes surprise friends and enemies alike: Benda as well as Herzog went into the court as conservative Ministers of the Interior and developed there into liberal Presidents.” (Bryde, 1998, p. 495, my translation - SM)

Still, the widely accepted finding of interactionist theory applies: As Gerhard Kette has put it: "factors of the person" have to "always to be considered in their interaction with relevant situational factors to explain behaviour" (Kette, 1994, p. 100, my translation - SM).

\section{Financing}

For their work, organisations need to be provided with appropriate material resources. As a rule, states try to save on the expense of the third power. "The real Code of Court Procedure is the budget legislation", is a saying in Russia. Before President Wladimir Putin repaired the power organs, a pauperisation of the courts took place. In the 1990ies, courts could not pay their utility bills and were cut off from electricity and gas. Endless procedures and daily malfunctions in the Italian justice are also partially an effect of poor resource allocation.

In Germany, a policy of saving makes itself much less felt. Cases are usually processed fairly quickly. The under-financing of the courts is most visible in the number of cases a judge is expected to bring to a solution ("Fallpensum", or "Schlagzahl"). The courts are determining the number of posts for judges by calculating, for example, a case load of 1200 per year for a single judge at the lower criminal court ("Strafeinzelrichter"). - The influence of the 
political parties on the resource allocation of courts makes itself felt mainly in a lack of interest.

\section{Information, Education, Coordination}

Article 21 of the German Federal Constitution gives parties the function to contribute to the formulation of the political will of the people. Influencing political opinion, political education and the coordination of political action are generally regarded as typical for parties. Such influences are also exerted on judges and prosecutors by means of information, education and coordination.

Social Democrats and Christian Democrats have lawyer associations. The Lawyer Working Group of the SPD ("Arbeitsgemeinschaft Sozialdemokratischer Juristen") initiated the journal "Recht und Politik" some forty years ago and they took part in many political debates. The CDU from the early times under Konrad Adenauer up to when Helmut Kohl presided literally lived as party out of its associations. The more astonishing is the shadow existence of its lawyer association ACDJ. Like other CDU-associations, it might have entered now a phase of artificial life extension.

The "Richterbund" forms the main lobby group of German judges and prosecutors. The association sees itself as non-partisan and since years it is no longer clearly conservative. The small group which regularly assembles for a "Richterratschlag" (judges' council) and which edits the lively insider-journal "Betrifft: Justiz" has little weight compared to the Richterbund. In Spain and France, however, judge associations which are close to political parties play an important role. Critics say the justice is fragmented, even more; the judges would act according to their parties' instructions. Freund (1979, p. 48), e.g., attacked French judges' unions for "turning their profession into an instrument of the opposition against the society" (my translation - S.M.). Similar allegations were made by Italian politicians. But the Tangentopoli-inquiries showed that this danger did not occur (see Nelken, 1996, pp. 106 and 111).

\section{Intervention in Individual Cases}

Government and party intervention in cases form a challenge for the justice system. In the Soviet Union, there was a term "telephone justice", meaning the intervention of the Communist Party and the secret services into the daily work of judges. Often, the judge first called the local party secretary to ask for instructions (Schroeder, 1995, p. 11). Smith (1996, p. 68) reports a survey of Soviet judges from 1988. Half of the judges had received suggestions by party and government officials during the last year. Another study estimated that party officials intervened in between 10 and 12 percent of all cases. The typical western country with strong party influence would be the U.S.A. But even here, there is less party influence because in the U.S., the political parties and the justice system are in principle separated, while the Communist Party of the Soviet Union claimed a universal power in Soviet society. Thus, involvement in daily legal affairs follows logically. Also, the role of the press and the public differs. To expose scandalous cases forms an objective of many U.S. journalists, scientists, writers and film makers (Note 8).

Interventions in inquiries and court cases prove to be rare in Germany, because they can easily be scandalised and because of strong constitutional provisions for judicial independence. Also, there seems to be a custom not to "interfere in a pending procedure" ("Eingriff in ein schwebendes Verfahren"). However, a few of incidents became public. In Saxony, e.g., the Justice Minister stopped the prosecutorial investigation against a former Minister who stood under suspicion of molesting a youth. The prosecutors later unveiled this incident before an investigatory commission of the Province Parliament (Burger, 2007). Interventions are more likely to affect the prosecution, since prosecutors are usually bound by orders. In the last years, there has been a rise of cases in which suspects publicised criminal inquiries against them. They claimed that "from above" machinations have been set to work to push them as political enemies aside. Some of these allegations even were about in-party disputes. Such accusations will be especially politically dangerous, if the public comes to believe that interventions are frequent.

\section{Conclusion}

Factors of the political structure and the "institutional design" of the state, the career paths and inner mechanics of the legal institutions and a nation's legal culture influence the degree of party power over the courts and the prosecutorial service. Some of these might be changed quickly by adjusting rules; others can only hardly be challenged by legal reformers. A comparison of different countries reveals a number of provisions which discourage illicit party influence: the separation of ordinary and "political-administrative" work in different branches of the courts, the greater diversity of a multi-party system, independent and watchful media, a career judiciary and prosecution, lay participation when not dominated by one party, are among those.

All in all, there is not much danger in Germany of overwhelming political transgressions into the third power. Ultimately, it is prevented by a legal-cultural fact: that the judicial independence is generally highly valued. This means that parties and other actors are to be kept away from the judge's bench. However, the shelter of prosecutors against questionable orders could be enhanced.

This leads to the core of the problem. Politics is not in vain a shifting concept between the Aristotelian idea of organising a good life on the one side and Weber's definition of a struggle for power on the other side (Weber, 
1919/1997). The "court arena" (Rüdiger Voigt) is a field of political action. The law-giver entrusts the judges with a large part of the political steering of the society (Voigt, 1986, pp. 13-14). By necessity the political parties have to also engage in politics on the judicial field. Only it has to be wisely limited.

Thus - and this is the possible explosive charge - the elements of the political system which are the least highly regarded by the public are exerting some influence on the most highly regarded subsystem of the state (Note 9). If the Federal President is set aside, the courts and above all the Federal Constitutional Court are evaluated most favourably in German opinion polls. But all who take part in daily power struggles like also the Federal Parliament, the provincial parliaments, the lobby groups, the unions find themselves on the bottom of the scale (Note 10). The public trust in institutions can be decisive for the survival of democratic systems. The history of the Weimar Republic forms an urgent warning. It can even be felt in daily life whether the citizens are inclined to engage socially, to obey the law, or to invest their resources in their country. The parties' influence on the third power is kept under surveillance by the public and rightly so.

\section{References}

Abraham, H. J. (1987). Introduction. In J. R. Schmidhauser (Ed.), Comparative judicial systems. London: Butterworths.

Asimow, M., Greenfield, S., Jorge, G,, Machura, S., Osborn, G., Robson, P., Sharp, C., \& Sockloskie, R. (2005). Perceptions of lawyers - A transnational study of student views on the image of law and lawyers. International Journal of the Legal Profession, 12, 407-436.

Blankenburg, E. (1995). Mobilisierung des Rechts. Berlin: Baden-Baden.

Bryde, B.-O. (1998). Die Verfassungsgerichtsbarkeit in der Rechtssoziologie. In J. Brand, \& D. Strempel, (Eds.), Soziologie des Rechts. Festschrift für Erhard Blankenburg (pp. 491-504). Baden-Baden: Nomos.

Buchsteiner, J. (2007a). Die religiöse Tankstelle. Frankfurter Allgemeine Zeitung, 9 July 2007, p. 3.

Buchsteiner, J. (2007b). Musharraf gibt Armeekommando ab. Frankfurter Allgemeine Zeitung, 29 November 2007, p. 8.

Buncombe, A., \& Waraich, O. (2007). A defiant message to Musharraf: we will keep fighting for justice. The Independent, 6 November 2007, p. 2-3.

Burger, R. (2007). Die Ehre der sächsischen Schlapphüte. Frankfurter Allgemeine Zeitung, 14 June 2007, p. 3.

Derlien, H.-U., \& Löwenhaupt, S. (1997). Verwaltungskontakte und Institutionenvertrauen. In H. Wollmann et al., Transformation der politisch-administrativen Strukturen in Ostdeutschland (pp. 417-472). Opladen: Leske und Budrich.

Easton, D. (1965). A systems analysis of political life. New York: Wiley.

Epstein, L., Knight, J., \& Shvetsova, O. (2001). The role of constitutional courts in the establishment and maintenance of democratic systems of government. Law and Society Review, 35, 117-163.

Fraenkel, E. (1968). Zur Soziologie der Klassenjustiz und Aufsätze zur Verfassungskrise 1931-32, Reprint. Darmstadt: Wissenschaftliche Buchgesellschaft.

Frankfurter Allgemeine Zeitung (2007a). Polen lässt keine ausländischen Wahlbeobachter zu, 24 September 2007, p. 6.

Frankfurter Allgemeine Zeitung (2007b). „Kaczynski fordert zum Rechtsbruch auf“, 28 July 2007, p. 1.

Frankfurter Allgemeine Zeitung (2007c). Regierungschaos in Polen“, 1 September 2007, p. 1-2.

Freund, J. (1979). Richter oder Rächer? In G.-K. Kaltenbrunner (Ed.), Auf dem Weg zum Richterstaat (pp. 44-61). München: Herder.

Fromme, F. K. (1979). „Karlsruhe: Wie es euch gefällt? In Kaltenbrunner, G.-K. (Ed.), Auf dem Weg zum Richterstaat (pp. 98-120). München: Herder.

Gawron, T., \& Schäfer, R. (1976). Justiz und organisierte Interessen in der BRD. In P. Graf Kielmannsegg (Eds.), Legitimationsprobleme politischer Systeme (PVS special issue 7/1976, pp. 217-269). Opladen: Westdeutscher Verlag.

Gelinski, K. (2004). Oberste Richter am jüngsten Gericht. Frankfurter Allgemeine Zeitung, 28 October 2004.

Grunwald, H. (2003). Party lawyers, political trials and judicial culture in the Weimar Republic. Dissertation, Cambridge University.

Häußermann, H. (1977). Die Politik der Bürokratie. Frankfurt at the Main: Campus.

Jacob, H. (1984). Justice in America. Boston: Little, Brown and Comp.

Juschtschenko, V. (2007). Angriff auf die Demokratie. Frankfurter Allgemeine Zeitung, 19 June 2007, p. 12.

Karpen, U. (1985). Die geschichtliche Entwicklung des liberalen Rechtstaats. Mainz: v. Hase \& Koehler.

Kette, G. (1994). Urteilsbildung bei Laienrichtern. Wien: Springer. 
Kisker, G. (1994). Das Bundesverfassungsgericht als Hüter der bundesstaatlichen Ordnung. In A. B. Gunlicks, \& R. Voigt (Eds.), Föderalismus in der Bewährungsprobe (2nd ed., pp. 61-83). Bochum: Brockmeyer.

Kramer, S. (producer/director). (1960). Inherit the wind [Motion Picture]. United States: United Artists.

Kramer, S. (director). (1961). Judgement of Nuremberg [Motion Picture]. United States: United Artists.

Kunig, P. (2001). Art. 21 (Politische Parteien). In P. Kunig (Ed.), v. Münch-Kunig Grundgesetz-Kommentar, Band 2, (5th ed., pp. 53-109). Munich: C. H. Beck.

Ladurner, U. (2007). Die Angst des Generals. Die Zeit, no. 27/2007, 28.6.2007, p. 6.

Langbein, J. H. (1985). The German advantage in civil procedure. The University of Chicago Law Review, 52, 823-866.

Legnaro, A. (2004). Mannesmann, geh du voran... Kriminologisches Journal, 36, 83-91.

Luhmann, N. (1983). Rechtssoziologie (2nd ed.) Opladen: Westdeutscher Verlag.

Luhmann, N. (1993). Das Recht der Gesellschaft. Frankfurt am Main: Suhrkamp.

Luhmann, N. (1999). Recht als soziales System. Zeitschrift für Rechtssoziologie, 21, 1-13.

Luhmann, N. (2000). Die Politik der Gesellschaft. Frankfurt am Main: Suhrkamp.

Machura, S. (2001). Fairness und Legitimität. Baden-Baden: Nomos.

Machura, S. (2003). Die Autorität der dritten Gewalt. In S. Machura, \& S. Ulbrich (Eds.). Recht, Gesellschaft, Kommunikation. Festschrift für Klaus F. Röhl (pp. 129-142). Baden-Baden: Nomos.

Machura, S. (2006). Ehrenamtliche Verwaltungsrichter. Münster: Lit.

Machura, S. (2007). Lay assessors at German administrative courts: fairness, power-distance orientation, and deliberation activity. Journal of Empirical Legal Studies, 4, 331-361.

Machura, S., \& Weiß, M. (2003). Mandatory lay mediation for small claims: a never-ending story in Germany. Paper for the panel "Lay judges and lay mediators: international perspectives I", Annual Meeting of the Law and Society Association 5-8. June 2003, Pittsburgh/Pennsylvania, USA.

Marder, N. (2003). Introduction to the jury at a crossroad: the American perspective. Chicago-Kent Law Review, 78, 909-933.

Meador, D. J. (1991). American courts. St. Paul/Minn.: West Publ. Co.

Meinke, U. (2003). Druck auf die Justiz kann Anklage nicht verhindern. Westdeutsche Allgemeine Zeitung, 8 February 2003.

Mejias, J. (2004). Florida von gestern. Frankfurter Allgemeine Zeitung, 16 October 2004, p. 36.

Montesquieu, C. de Secondat, Baron de (1748/1974). Vom Geist der Gesetze (translated by K. Weigand). Stuttgart: Reclam.

Müller, I. (1980). Rechtsstaat und Strafverfahren. Frankfurt at the Main: Europäische Verlagsanstalt.

Nagel, S. S. (1975). Improving the legal process. Lexington, Mass.: Lexington Books.

Nelken, D. (1996). The judges and political corruption in Italy. Journal of Law and Society, 23, 95-112.

Neumann, H. (1979). Uferlose Verwaltungsgerichtsbarkeit - der zum Richterstaat pervertierte Rechtsstaat. In G.-K. Kaltenbrunner (Ed.), Auf dem Weg zum Richterstaat (pp. 152-169). Munich: Herder.

Niedermayer, O. (2001). Bürger und Politik. Wiesbaden: Westdeutscher Verlag.

Parikh, S. (2003). Plaintiff's practicioners. Researching Law, 14, no. 4, 2-7.

Peitsmeier, H. (2004). Sieg ohne Victory-Zeichen. Frankfurter Allgemeine Zeitung, 23 July 2004, p. 3.

Pinello, D. R., (1999). Linking party to judicial ideology in American courts: a meta-analysis. The Justice System Journal, 20, no. 3, 219-254.

Polaczek, D. (2002). Status corruptionis. Frankfurter Allgemeine Zeitung, 16 February 2002.

Popitz, H. (1968). Über die Präventivwirkung des Nichtwissens. Tübingen: Mohr.

Rautenberg, E. C. (2000). Der Generalstaatsanwalt: ein „,politischer Beamter“? Deutsche Richterzeitung, 78, 141-147.

Röhl, K. F. (1987). Rechtssoziologie. Köln: Heimann.

Röhl, K. F., \& Weiß, M. (2004). Evaluierung des nordrhein-westfälischen Ausführungsgesetzes zu $\S 15$ a EGZPO. Gutachten erstellt im Auftrag des Landtags Nordrhein-Westfalen, Bochum, May 2004 (on file with the author).

Röhl, K. F., \& Weiß, M. (2005). Die obligatorische Streitschlichtung in der Praxis. Münster: Lit. 
Rottleuthner, H. (1987). Einführung in die Rechtssoziologie. Darmstadt: Wissenschaftliche Verlagsgesellschaft.

Rudolph, K. (1998). Die politische Abhängigkeit der Staatsanwaltschaft. Neue Juristische Wochenschrift, 51, pp. 1205-1206.

Rüther, B. (2002). Reise in den Richterstaat. Frankfurter Allgemeine Zeitung, 15 April 2002, p. 7.

Ruggiero, V. (1996). France: corruption as resentment. Journal of Law and Society, 23, 113-131.

Säcker, H. (1989). Das Bundesverfassungsgericht (4th ed.), Bonn: Bundeszentrale für Politische Bildung.

Scharpf, F. W. (1970). Die politischen Kosten des Rechtsstaats. Tübingen: Mohr.

Schmid, R. (1975). Das Unbehagen an der Justiz. München: Beck.

Schroeder, F.-C. (1995). Recht und Rechtspflege in Rußland nach dem Sozialismus. Jahrbuch für Ostrecht, 36, pp. 9-28.

Schroeder, F.-C. (1998). Einführung. In Strafgesetzbuch der Russischen Föderation (translated by F.-C. Schroeder \& T. Bednarz, pp. 1-37). Freiburg im Breisgau: Edition Iuscrim.

Schuller, K. (2007a). Die Taktik der Kriegspartei. Frankfurter Allgemeine Zeitung, 11 June 2007, p. 5.

Schuller, K. (2007b). Einigung am Rande des Abgrunds. Frankfurter Allgemeine Zeitung, 29 May 2007, p. 3.

Schuller, K. (2007c). Politik des Ausnahmezustands. Frankfurter Allgemeine Zeitung, 7 September 2007, p. 12.

Schwan, A. (1991). Politische Theorien des Rationalismus und der Aufklärung. In H. J. Lieber (Ed.), Politische Theorien von der Antike bis zur Gegenwart (pp. 157-257). Bonn: Bundeszentrale für Politische Bildung.

Smith, G. B. (1996). Reforming the Russian legal system. Cambridge: Cambridge University Press.

Spielberg, S. (producer/director). (1997). Amistad [Motion Picture]. United States: Dream Works.

Strohmeier, G. (2004). Die Gewaltenteilung in der politischen Theorie - Entwicklungslinien. In W. Gellner, \& A. Glatzmeiner, Macht und Gegenmacht. Einführung in die Regierungslehre (pp. 41-61). Baden-Baden: Nomos.

Tobin, R. W. (1999). Creating the judicial branch. The unfinished reform. Williamsburg, VA: National Center for State Courts.

Voigt, R. (1986). Steuerung der Gesellschaft durch Recht? Ein Beitrag zur Rechtspolitologie. In R. Voigt (Ed.), Neue Zugänge zum Recht. Law and Legal Science (pp. 3-25). Siegen: Forschungsschwerpunkt Historische Mobilität und Normenwandel; Universitaet - Gesamthochschule - Siegen.

Vorländer, H. \& Brodocz, André. (2006). Das Vertrauen in das Bundesverfassungsgericht. Ergebnisse einer empirischen Bevölkerungsumfrage. In H. Vorländer (Ed.), Die Deutungsmacht der Verwaltungsgerichtsbarkeit (pp. 259-295). Wiesbaden: VS-Verlag.

Weber, M. (1922/1973). Gesammelte Aufsätze zur Wissenschaftslehre (4th ed., edited by Johannes Winckelmann). Tübingen: Mohr.

Weber, M. (1922/1980). Wirtschaft und Gesellschaft (5th ed., edited by Johannes Winckelmann). Tübingen: Mohr.

Weber, M. (1919/1997). Politik als Beruf. In M. Weber, Schriften zur Sozialgeschichte und Politik (edited by M. Sukale). Stuttgart: Reclam.

Werle, R. (1975). Die Unabhängigkeit der Richter aus der Sicht der Richter. In E. Blankenburg (Ed.). Empirische Rechtssoziologie (pp. 146-172). München: Piper.

\section{Notes}

Note 1. For examples see Rüther, 2002; Müller 2007. The speakers of both big parties in the election committee for judges are described as "Königsmacher" (king-makers).

Note 2. Whoever wants to assess the parties' influence on the third power comes across a problem of classification, which is not always easily solved. Not any initiative of a politician is to be ascribed to his party. Take an example which was told by a judge. The justice minister of a province intervened repeatedly in favour of a special friend, who became a suspect in a criminal investigation. Such a case surely counts as a political influence, because only the public office allowed the exercise of pressure. It would become a case of party-political influence if, for example, the beneficiary would not only be an old friend, but if he facilitated as a member of a political rope team the advancement of the minister in his party and now ostensibly has the right to be protected. - Thus party influence has to deal with the politics of a party or with power struggles in a party to be relevant for our topic.

Note 3. Parties may also possibly turn the courts' and public prosecution's legal routines against them. For example, during the Republic of Weimar (1919-1933), extremist parties turned criminal proceedings against their followers into 
political spectacles. Henning Grunwald (2003, iv) mentions 15 employees of the German Communist Party who co-ordinated the work of up to 200 lawyers. Their aim was not the classical defence of the accused but the public dramatisation of the trials for propaganda purposes, the showing up of the justice and the Weimar democracy. A corresponding strategy was pursued by the NSDAP. "Extremist lawyers used the alleged non-attainability of justice for fundamental political dissenters to advocate replacing the Republic with a radically different political order", Grunwald (2003, iv) summarised.

Note 4. Some of the author's (SM) interview partners reported quite openly. However, a survey was forbidden on one occasion. Having had already the permit of the Province Minister of Justice to use the addresses held by the courts, the President of the Provincial Administrative Court stopped the project with a letter to the lower courts. In the questionnaire, he had found a question for the party preference of the judges. Perhaps, he speculated on a kind of "preventive effect of not knowing". "Präventivwirkung des Nichtwissens" has been a book title by Popitz (1968) about norm violations.

Note 5. A colleague of the author once returned from a regional gathering of the lay mediators and reported: "There were three city mayors, two members of the Province Parliament, further politicians - but only 43 lay mediators".

Note 6. Similar Langbein, 1985, p. 853. Similar for the German Federal Constitutional Court: Kisker, 1994, p. 64. Earlier, Fromme (1979, p. 118) suggested that the parties restrained themselves after suffering from public criticism. Analysing reasons for the good functioning of the Constitutional Court, Säcker (1989, p. 44) emphasized the requirement of a two-thirds majority for judge elections and the fact that judging is primarily content-orientated.

Note 7. Marder, 2003, p. 911; Parikh, 2003, pp. 2-3; Tobin, 1999, p. VIII. Meador (1991, p. 59) draws a connection to costly but probably decisive TV-election spots.

Note 8. Novels, films and TV broadcasts often depict political pressures on prosecutors and judges. Some of them are written by insiders like the former lawyer John Grisham. As examples for historic interventions which are the basis for movies: "Amistad" (Spielberg, 1997) shows how the interests of the slave economy were protected, "Inherit the Wind" (Kramer, 1960) deals with a debate on opposing world views and the influence of upcoming elections, "Justice of Nuremberg" (Kramer, 1961) shows the growing acceptance for Nazis when the Cold War broke out.

Note 9. Yet, there are countries, where the courts are held in low prestige because of overwhelming political influence, like e.g. Argentine. See Asimow et.al, 2005, p. 415.

Note 10. Derlien \& Löwenhaupt, 1997, pp. 458-460 and 470; Niedermayer, 2001, p. 66. The more recent survey reported by Vorländer and Brodocz (2006, p. 262) shows the Federal Constitutional court and the police, followed by the Federal President on top of a scale of public trust and the political parties at the very end.

Table 1. Comparison of Party Preferences of Lay Assessors in East and West Germany

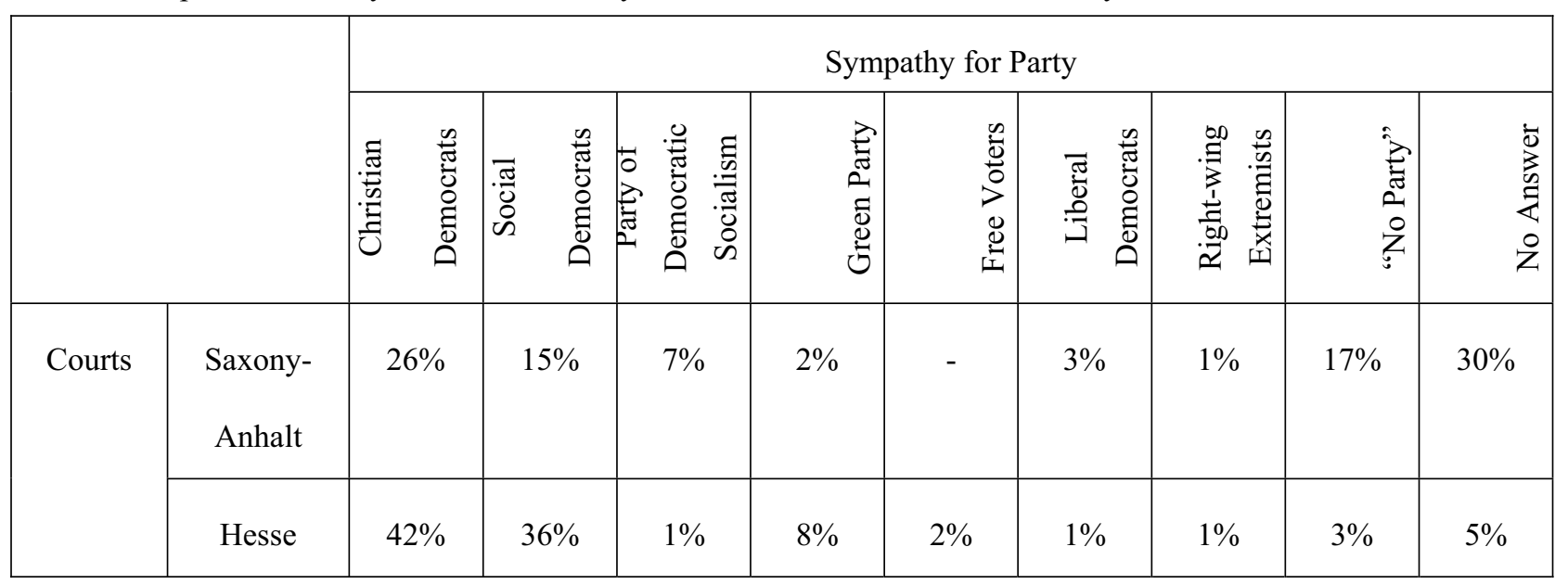

Lay assessors of administrative courts, Hesse and Saxony-Anhalt, 2 000, $n=299$ (of which Hesse: 154). Item "If you feel close to a political party, to which?", Cramer's V =.512, p <.001. Source: Machura 2006, p. 32. 